\title{
AКTУАח
}

\section{Від редакції}

Більшість світових лідерів різко негативно відредагували на анексію Криму та вторгнення російських військ на територію України. Російська Федерачія порушила міжснародні домовленості, що виписані не тільки між Украӥною і Росією, але і низку міждержавних угод про визнання територіальних кордонів та територіальної иілісності держав.

Такі дії РФ відображені в реакиії багатьох держав світу, висвітлені в численних публікаціях, у проведенні різних форумів, у тому числі $і$ в Украӥні. Начіональний комітет географів Украйни із залученням іноземного експерта вперше провів спеиіальне дослідження впливів на життя $i$ професійну діяльність географів Украӥни внаслідок вторгнення військ РФ на ї̈ територію. Впливи вторгнення різнобічні, і ия публікація, очевидно, є одним з можливих аспектів щодо висвітлення всіх його наслідків.

УДК 911.375:330

DOI: https:10.16407/ugz2020.02.003

\author{
С. Д. Бранн1, О. Л. Дронова², Л. Г. Руденко 2 О. М. Лейберюк ${ }^{2}$ \\ 'Університет Кентуккі, Лексінгтон, США \\ ${ }^{2}$ Інститут географрії НАН України, Київ, Україна
}

\section{ВПЛИВ РОСІЙСЬКОÏ АГРЕСІЇ НА СТАН РОЗВИТКУ ГЕОГРАФІЇ В УКРАЇНІ}

Вперше з врахуванням існуючих публікацій висвітлено результати дослідження впливу військового вторгнення Російської Федерації в Україну у 2014 р. на життя і професійну діяльність географів України. Дослідження здійснено за ініціативою Національного комітету географів України. Наголошено на недотриманні міжнародних угод щодо непорушності кордонів і територіальної цілісності держав.Отримані результати на основі опитування за розповсюдженими спеціальними анкетами серед членів Українського географічного товариства, що проживають в різних регіонах України, забезпечили можливість виявити важливі негативні впливи вторгнення на професійну діяльність географів держави, на їх стосунки із фахівцями Росії, Криму та тих, що лишились на окупованій території Донбасу, на погіршення їх сучасного життя та життя сімей, на зміни в орієнтації подальших творчих стосунків із географами сусідніх держав. Констатовано, що події, які відбуваються на Сході України внаслідок вторгнення військових формувань в Україну призвели до значних змін у професійній діяльності географів України (зміна програми викладання предметів, потреба підготовки нових підручників, значна активізація публічних виступів, переорієнтація у виборі полігонів досліджень і проведення наукових і виробничих практик, припинення використання публікацій науковців із Росії, творчих стосунків із російськими колегами тощо), а також до значних змін в особистому житті (зміна місця роботи і місць проживання, пошуки роботи та житла для сімей після переїзду з окупованих територій, психологічних навантажень у зв'язку з втратою набутого статусу, розривом родинних зв'язків, необхідністю адаптування до нових умов проживання, в нових колективах і таке інше). За таких умов активізувалися волонтерські рухи і намагання до консолідації зусиль з метою відновлення територіальної цілісності України та ії самостійного вектора розвитку.

Ключові слова: військове вторгнення; наукова спільнота; Украӥнське географічне товариство; Україна; Донбас; Крим; тимчасово окуповані території.

\section{S. D. Brunn', O. Dronova², L. Rudenko', O. Leiberiuk ${ }^{2}$}

${ }^{1}$ University of Kentucky, Lexington (USA)

${ }^{2}$ Institute of Geography of the National Academy of Sciences of Ukraine, Kyiv

THE INFLUENCE OF THE RUSSIAN AGGRESSION ON THE STATE OF DEVELOPMENT OF GEOGRAPHY IN UKRAINE

The research is the first that highlights the results of a study of the military invasion by the Russian Federation into Ukraine in 2014 on the life and professional activity of geographers of Ukraine. The study was initiated by the National Committee

() С. Д. Бранн, О. Л. Дронова, Л. Г. Руденко, О. М. Лейберюк, 2020

ISSN 1561-4980. Укр. геогр. журн. 2020, 2(110) 
of Geographers of Ukraine. It indicates non-compliance with international agreements on the inviolability of borders and the territorial integrity of states. The results obtained by the special questionnaires distributed among the members of the Ukrainian Geographic Society living in different regions of Ukraine, revealed important negative effects of the invasion on the professional activity of geographers of the state, on their relations with specialists from Russia, Crimea and those who remained in the occupied territories. The study also showed the deterioration of their everyday and family life, and changes in the orientation of further creative relations with geographers of neighboring states. The findings of the study indicate that the invasion of military formations in Ukraine led to: - radical changes in the professional life of all geographers of Ukraine (change of the program of teaching subjects, the need to prepare new textbooks, significant intensification of public speeches, reorientation in the selection of research sites and conduct scientific and industrial practices, the termination of the use of Russian scientists' publications, the termination of creative relations with Russian colleagues, etc.); - significant changes in the personal lives of geographers (changing jobs and places of residence, finding housing for families after moving out of the occupied territories), many specialists experience constant sorrow for the difficult times and longing for the past, among these are often abandoned parents, children, relatives, the feeling of stress that does not go away, activation of volunteer movements and attempts to consolidate the efforts of people of different ages in order to restore the territorial integrity of Ukraine and its independent vector of development.

Keywords: influence; military invasion; scientific community; Ukrainian Geographical Society; Ukraine, Donbass; Crimea; temporarily occupied territories.

\section{Актуальність теми дослідження}

Турбуючись про мирне майбутнє розвитку світу, 1 серпня 1975 р. глави 35 держав підписали заключний акт Наради з безпеки і співробітництва в Європі [1]. Міжнародні домовленості містили розділи з гуманітарної сфери співробітництва в міжнародно-правовій, військово-політичній та економічній сферах. Крім інших важливих позицій акту, узгоджено політичні й територіальні підсумки Другої світової війни, принципи непорушності кордонів, територіальної цілісності держав і невтручання у внутрішні справи іноземних держав. Після розпаду СРСР (1991) колишні радянські республіки стали незалежними державами і були сприйняті як нові члени світової політичної спільноти. Військове вторгнення Росії в Україну у 2014 р. стало демонстрацією намагання перекроїти політичну карту Свропи, свідченням несприйняття домовленостей щодо європейських кордонів та ігноруванням Гельсінкських (1975), Будапештських (1994) та інших міжнародних угод країною, яка мала, згідно цих угод, гарантувати територіальну цілісність України та недоторканність іiі кордонів.

Впливу Російсько-Українського військового конфлікту зазнали 9\% території і 20\% населення України, втрачено контроль за 409 км міжнародно визнаного кордону з РФ [2]. 64 українських міста (46 на Донбасі та 18 - у Криму) з населенням понад 4,5 млн осіб знаходяться на непідконтрольних державі територіях [3]. На початок 2019 р. 3 тимчасово окупованих територій Донецької та
Луганської областей та Криму в Україну переміщено 1,5 млн мігрантів [4]. Військові дії у регіоні спричинюють демографічні втрати, руйнацію економіки, інфраструктури, систем розселення, стану довкілля, рівня життя, усталених зв'язків у зоні конфлікту та за його межами. Цим та іншим питанням присвячено значну кількість досліджень, як в Україні, так і за кордоном [5-8].

Події на Донбасі також стосуються різних груп українського суспільства, навіть тих, хто не проживає на тимчасово окупованих територіях. Військові дії впливають на системи цінностей, погляди, зв'язки та уподобання багатьох українців, у тому числі в наукових спільнотах, які вивчають просторову організацію суспільства.

Напрямки наукових досліджень і навчальних програм зазнають змін внаслідок, наприклад, впровадження інновацій чи нових трендів державної політики. Окремі зміни можуть бути «нав'язані» науковим та освітянським спільнотам внаслідок екстремальних зовнішніх та внутрішньодержавних подій, що впливають на їхнє повсякденне професійне та особисте життя. Деякі зміни виникають внаслідок військових конфліктів та загроз територіальній цілісності країни. Чи можливо розглядати військову агресію сусідньої держави як поштовх для подолання наукової маргіналізації та інструмент для формування сильнішої наукової спільноти в пострадянській країні? Наша відповідь - так.

М е т о ю статті є висвітлення результатів дослідження впливу військової агресії Росії в Україну 
у 2014 р. на життя та професійну діяльність представників української географічної спільноти, здійсненого авторами вперше в Україні у 2018-2019 роках.

\section{Теоретичне та методичне підгрунтя виконаного дослідження}

Зміни напрямів досліджень є передбачуваними, оскільки фахівці різних дисциплін в рамках своїх наукових можливостей та інтересів прагнуть визначити інтегральні чи акумулятивні ефекти, прямі та опосередковані політичні, соціальні, культурні, екологічні чи просторові наслідки вторгнення. Основою таких досліджень стають особистісні спрямування, цінності й пріоритети, відчуття приналежності та відповідальності, намагання коригувати свої пріоритети у зв'язку 3 новими і несподіваними реаліями. Різні аспекти російської агресії перебувають в центрі досліджень політологів, істориків, географів, журналістів та інших [9-11]. Кузьо [12] зазначив, що події на Сході України і в Криму внаслідок військового вторгнення стали темою майже 400 наукових монографій і статей.

Окремі дослідження присвячені причинам і передумовам вторгнення $[13,14]$, російсько-українським відносинам, культурним особливостям i розбіжностям, економіці та повсякденному життю мешканців південного сходу України та Криму [15-17]. Зокрема Т. Маляренко [18] наголошує на тривожній політичній ситуації, що передувала вторгненню та сприяла зростанню взаємної недовіри та ескалації суперечок. Інші оцінюють результати виборів та опитування громадської думки після вторгнення [19-21], акцентуючи увагу на впливові на місцеві громади. На думку деяких дослідників [22] вторгнення до східних регіонів України і в Крим може розглядатися як показник барометра стосовно можливих подальших військових загроз іншим країнам-сусідам Росії.

Значну кількість досліджень присвячено міграціям, спричиненим конфліктом і особливостям життєдіяльності внутрішньо переміщених осіб [6], акцентуючи увагу, зокрема, на зростанні кількості внутрішніх мігрантів, на соціальній підтримці вимушено переміщених осіб [23], на питаннях психологічного стану постраждалих [24] тощо.

Наукові напрацювання свідчать про те, що вторгнення на Схід України та анексія Криму вписуються у військову та геополітичну стра- тегію російських владних сил, спрямовану на одночасну делегітимізацію українського уряду і збентеження Заходу [11]. Дії Росії чітко свідчать про намагання встановлення довготривалого впливу на внутрішню та зовнішню політику України [7, 25].

Політичні, економічні та соціальні причини та наслідки тимчасової втрати контролю над окремими територіями України аналізують з позиції національної безпеки України [26]. Автори визначають умови реінтеграції, пріоритети та прогнози відновлення Донбасу та Криму. В. П. Горбулін $[27,28]$ піднімає питання про відносини України і Росії у новому типі протистояння, який автор називає «гібридною війною». У цьому протистоянні всі сторони зазнають значних втрат: Україна - від тривалого конфлікту на іï території, Росія - від участі в цьому конфлікті, а також від міжнародних санкцій; західні країни - від розриву економічних зв'язків із Росією.

Разом $з$ тим у наукових працях останніх часів підкреслюються й прогресивні зміни у суспільстві, які «запускає» цей конфлікт. Зокрема, стосовно України можна відзначити прискорення зростання соціального капіталу i формування української політичної нації на основі патріотизму і налагодження нової системи зв'язків, виникнення реальної свободи слова, що сприяє формуванню демократичного громадянського суспільства, яскравим проявом якого є масовий $\mathrm{i}$ активний волонтерський рух $[5,29]$.

Зазначені та інші напрацювання створюють основу для проведення різних опитувань у контексті поставленої мети дослідження. Звужуючи цільову групу до окремої наукової спільноти, автори намагалися з'ясувати, які зміни відбулися у світоглядних орієнтирах, напрямках досліджень, наукових, освітянських, особистих зв'язках українських географів. Результати щодо впливу військового вторгнення на життя й діяльність географів отримані на базі анкетного онлайн опитування респондентів, що проживають у різних регіонах України. Анкети були надіслані 150 членам Українського географічного товариства, контактні дані яких є в базі Інституту географії НАН України, залучено також персональні зв'язки. Анкети не розсилали мешканцям тимчасово окупованих територій, оскільки автори не хотіли ставити їх під загрозу репресій.

Отримано 79 відповідей. Головні блоки анкети (всього 75 запитань на 6-ти сторінках) вклю- 
чали питання щодо впливу військової агресії на: 1) професійне повсякденне життя, включаючи наукові дослідження чи освітянську діяльність; 2) характер контактів, які були і збереглися з колегами у Східній Україні та Криму, та 3 тими, хто в Росії; 3) професійні контакти 3 науковими спільнотами в інших країнах; 4) публікації та професійні відрядження; 5) дослідницькі/освітні напрямки; 6) особисте життя, родину та друзів. Запропоновані варіанти відповідей: практично не вплинуло, трохи, певною мірою, значно.

Анкетування здійснено за підтримки членів Українського географічного товариства, які працюють у закладах вищої освіти, наукових та громадських установах. Більшість респондентів (57), що надали відповіді на анкети, є працівниками закладів вищої освіти (21 професор, 26 доцентів, 5 асистентів, 5 викладачів), інші - наукові співробітники (19), студенти (2), 1 підприємець. Це, а також методика складання запитань анкети, специфіка відповідей та глибина коментарів дає підстави розглядати дослідження як експертне оцінювання.

\section{Виклад основного матеріалу \\ Демографічні, гендерні, регіональні відмін- ності}

Кількісні показники та особисті коментарі формують суть аналізу та дискусії, що наводяться далі. Із 79 респондентів 54 (68 \%) були віком від 31 до 60 років, 10 - до 30 та 15 - понад 60 років. Оцінка результатів опитування свідчить, що відповіді географів віком понад 50 років були дещо детальнішими та містили більше особистих коментарів, ніж відповіді молодших колег. Старше покоління географів звертало увагу, зокрема, на неможливість проведення практик і польових досліджень внаслідок вторгнення, насамперед в Криму. Однак, необхідно відмітити, що загальне скорочення таких поїздок відбулося ще до подій 2014 р. внаслідок браку фінансування досліджень у незалежній Україні. Також саме старше покоління вказало на розрив зв'язків 3 колегами з Росії, тоді як молодші колеги не виявили подібних настроїв, оскільки ще не встигли напрацювати відповідних контактів. Разом з тим, усі вікові групи географів Харківської та Дніпропетровської областей відзначили, що з 2014 р. втрачено можливості для проведення спільних виїзних наукових та навчальних поїздок на Сході України.

Відповіді респондентів віком до 40 років були дещо стриманішими, ніж їх старші колеги. Для цієї групи проблемою при проведенні досліджень були відсутність наявних статистичних даних 3 окупованих територій. Також молодші географи виявилися більш залученими до волонтерського руху та інших громадських заходів. Приклад:

«Вторгнення викликало необхідність приєднатися до волонтерського руху, щзоб підтримати учасників антитерористичної операції» (жінка вікової групи 31-40 років з м. Корець).

Зауважимо, що об'єднання та участь у громадських рухах для допомоги Сходу України підштовхнуло до вирішення інших нагальних проблем, наприклад муніципальних у власному місті.

Щодо співвідношення за статтю, було отримано 38 відповідей від жінок і 41 - від чоловіків. 3155 індивідуальних коментарів 95 (60 \%) надали жінки, а 62 (40 \%) - чоловіки. Виявлені деякі гендерні відмінності в кількості коментарів щодо конкретних питань. Географи-жінки надали більше коментарів про те, як вторгнення вплинуло на їх сім'ю, ніж чоловіки (7 до 3), про наслідки вторгнення на їх дослідження (7 до 4), про вплив на студентів та аспірантів (6 до 4), як це вплинуло на їх викладання (7 до 5) та дослідницьку програму (7 до 5). Чоловіки надали більше коментарів лише в одній з основних категорій, а саме як вторгнення вплинуло на їхню польову роботу та викладання в аудиторії (7 до 4). Кількість коментарів була майже однаковою щодо того, які теми досліджень потребують уваги внаслідок вторгнення.

Специфіка відповідей простежувалась також залежно від місця проживання респондентів та його зміни з моменту вторгнення, зміни мобільності фахівців тощо. Більшість відповідей надійшло з Києва (рис. 1). Існують певні відмінності між відповідями тих, хто живе поруч із зонами конфлікту, і тих, хто проживає далеко від них. Відзначено, що географи в Західній Україні не зазнали такого негативного особистого і професійного впливу як ті, хто проживав на окупованих територіях чи живе на Сході України й нині. Однак співчуття, реакція на вплив і активні дії - це часто залежить більше від пріоритетів та сумління людини, ніж від місця проживання.

\section{Вилив на професійну діяльність}

Експертний рівень опитування підтверджується тим, що майже 90\% респондентів мали наукове звання кандидата та доктора наук (43 і 27 відповідно). Лише 7 мали ступінь магістра та 2 були студентами. Респонденти представили широкий 


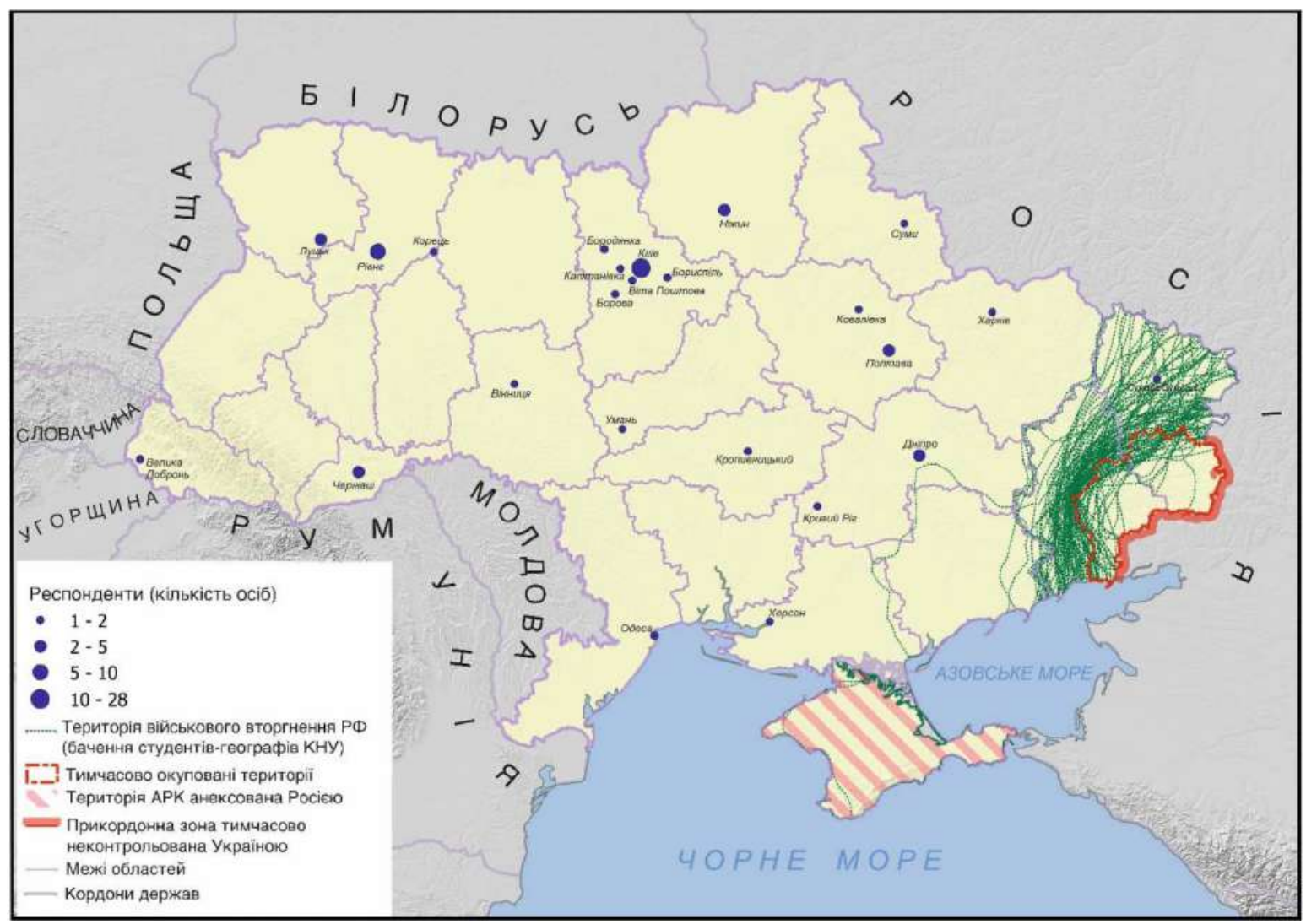

Puc. 1. Локації місць анкетного опитування та сприйняття тимчасово окупованих територій України студентами - географами

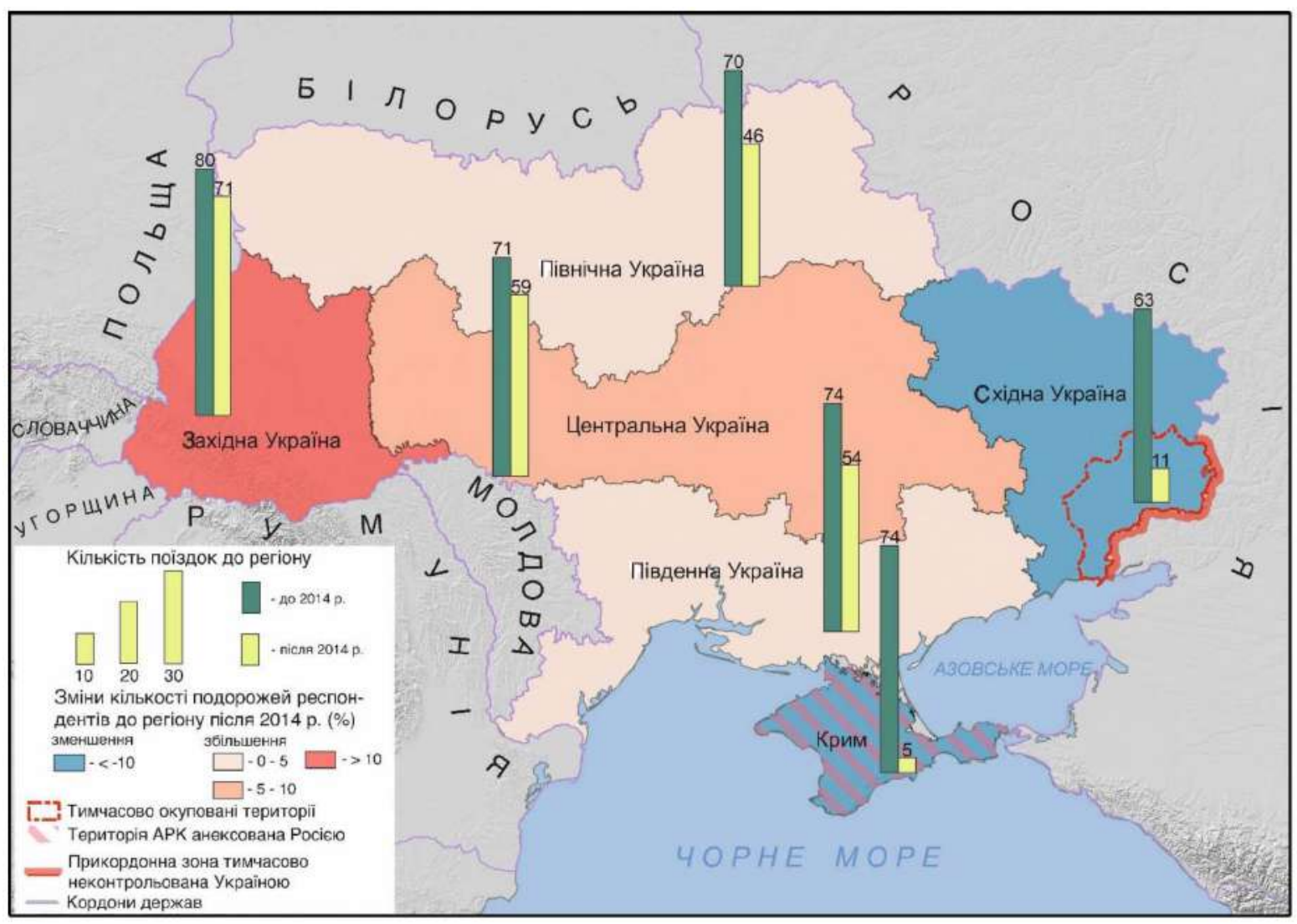

Puc. 2. Подорожі респондентів по Україні до і після російської агресії у 2014 р. 
спектр наукових інтересів, включаючи суспільну, природничу, політичну географію, екологічний менеджмент, картографію, туризм та інші напрями. На запитання про можливості потенційних досліджень, пов'язаних 3 вторгненням російських військ на Сході України, суспільні географи зосередилися на соціо-економічних питаннях, геополітиці, економіці, міграціях та культурі; тоді як природничники висловили інтерес до вивчення екологічних ризиків та загроз у зоні конфлікту.

3 метою аналізу впливу вторгнення на мобільність фахівців 3 питань просторового розвитку анкета включала питання про поїздки регіонами України до 2014 р. і після. Майже всі респонденти зазначили, що до вторгнення подорожували практично всіма регіонами держави без обмежень (рис. 2), після вторгнення менше 5\% подорожували на Схід України та у Крим.

«Я позбавлена можливості праџювати із своїми колегами у Криму, але ще більше постраждали вони, оскільки втратили свої традиційні об'єкти дослідження» (жінка вікової групи 61-70 років, Київ).

Викладачі закладів вищої освіти швидко відреагували на події на Сході України, включивши матеріали про вторгнення до програм початкових (32 респонденти) та старших (37) курсів, у тому числі основи суспільної географії України, політичної, урбаністичної, історичної географії, географії населення, транспорту, туризму, а також геополітики, антропогенного ландшафтознавства, просторового планування та розвитку, ГІС та картографії, засад наукової методології, наукової роботи у вищій освіті. Окрему увагу приділено географії Донбасу. 11 професорів також презентували лекції про вторгнення для студентів інших спеціальностей.

Загалом більшість викладачів (64 \%) зазначили, що вторгнення вплинуло на їх штатну/викладацьку роботу, проведення виїзних практик та стажувань «значно» та «певною мірою». Результати опитування стосовно впливу на студентів та аспірантів виявили певну градацію: 19 відповіли «значно», 29 - «певною мірою», 16 - «трохи» i 2 - «практично не вплинуло», 13 - не мають студентів чи аспірантів.

«Майже всі дисиипліни, які я викладаю, зміненi» (чоловік вікової групи 41-50 років, переселенець 3 Луганська).

«Станом на 2015 рік 60\% натих студентів були з Луганської та Донеиької областей та Криму» (жінка вікової групи 51-60 років, Харків). «...деяких студентів ие (вторгнення - прим. авт.) торкнулося мало, проте є студенти-заочники, колишні випускники, які беруть участь в OOC» - (чоловік вікової групи 51-60 років, Нiжин).

Окремі питання анкети стосувалися впливів на дослідницьку діяльність, 26 респондентів відповіли, що вторгнення «певною мірою» вплинуло на їх дослідницьку програму, а 14 відмітили «значно». 3 іншого боку, 24 відповіли «практично не вплинуло», 15 - «трохи». Вплив відбувся внаслідок втрати контактів з колегами з Донбасу, Криму, Росії, браку сучасної статистики з окупованих територій, а також внаслідок змін попередніх програм досліджень. Окремі зауваження демонструють розчарування у втраті траєкторій досліджень, i, разом з тим, готовність скористатися можливістю вивчати нові питання, спровоковані вторгненням.

Наступні блоки стосувалися впливу вторгнення на друзів-географів в Україні. Більше половини 48 (68\%) відповіли «певною мірою», 17 (24\%) - «значно», лише 11 відповіли «трохи» та «практично не вплинуло». Ці результати - ще один приклад, що показує відмінності в особистих стосунках і особистому сприйнятті.

Майже всі респонденти вказали, що важливо на лекціях говорити про вторгнення (75) і проводити дослідження його наслідків (74). На запитання про те, які ресурси можна використовувати для представлення інформації про вторгнення з наданого переліку (показ карт; робота з Інтернет-джерелами; відвідання музеїв; інтерв'ю; огляд газет; обговорення телевізійних передач; участь у волонтерському русі), найчастішими відповідями були показ карт (51 респондент) та використання Інтернет-джерел (48) ${ }^{1}$. Вважають, що невід'ємною частиною багатьох лекцій $є$ карти.

Але опитування підтвердило, що на нинішніх навчальних картах не позначені конфліктні райони. «Карта України в моєму класі не відображає тимчасово окупованих територій» - таку відповідь надали 63 респонденти (80\%). Це закономірно, напевне, оскільки Україна завжди розглядає ці території як частини України. Також викладачі були не впевнені, чи студенти могли б чітко визначити тимчасово окуповані території.

Для перевірки цього питання 90 студентам географічного факультету Київського національного університету імені Тараса Шевченка було запро-

${ }^{1}$ Надавалася більше ніж 1 відповідь.

ISSN 1561-4980. Ukr. geogr. ž, 2020, 2(110) 
поновано нанести лінії, що відмежовують тимчасово окуповані райони України на чисті контурні карти держави. Компіляція результатів наведена на рис. 1. Картосхема демонструє, що студентигеографи чітко розрізняють регіон конфлікту, який у їхньому сприйнятті корелює переважно 3 межами областей, які часто згадуються 3МI, a не 3 конкретними тимчасово окупованими територіями.

I викладачі, і фахівці наукових закладів однозначно відзначили вплив військових дій на світоглядні позиції:

«Війна змінюе кожного, оскільки вона впливає на світогляд» (жінка вікової групи 61-70, Київ).

«Україна ніколи не буде такою, як раніше, так само, як $і$ Донбас, джерело подій, шуо не мають зворотного шляху. Неможливо заперечувати роки війни, крові та страждань людей» [28, с. 6].

Загалом виділено кілька шляхів впливу вторгнення на професійну діяльність:

- порушення наукових та освітянських зв'язків викладачів і науковців з окремими представниками наукової спільноти та 3 певними регіонами (Крим, Схід України, Росія).

- припинення відряджень, спільних досліджень, участі у конференціях, практик та інших поїздок до Криму, Східної України та Росії.

- відсутність статистичних даних стосовно окупованих територій, що перешкоджає дослідженню всієї території України як єдиної господарської, соціокультурної чи розселенської системи.

- вивчення й викладання питань вторгнення $€$ важливим для фахівців, однак відсутність нанесення зон конфлікту на навчальних картах спричинює похибку у сприйнятті реальної ситуації студентами.

- основний вплив пов'язаний з тим, що відбулися кардинальні зміни світогляду кожної людини, усвідомлення «крихкості усталеної картини світу».

\section{Opiєнтир на Захід, а не на Cxid}

Ряд питань анкети стосувався контактів респондентів 3 російськими колегами. Автори усвідомлюють значний вплив російської географічної школи на формування світогляду українських географів, особливо старшого покоління за радянських часів і після здобуття Україною незалежності. Російська географія була пов'язана 3 фундаментальними та теоретичними підходами у всіх сферах як у радянський, так і в пострадянський періоди. На формування вітчизняного дисциплінарного світогляду значно вплинуло також знання російської мови. Багато вітчизняних підручників та дисертаційних досліджень базувались на російських першоджерелах і спільних напрямах розвитку географічної науки, визначених на всесоюзних географічних наукових форумах. Передумова такого підходу до передачі знань виникла в результаті багатьох років політики централізації за часів СРСР. Тоді ж було сформовано довготривале спільне наукове поле діяльності географів колишніх республік. Багато науковців старшого віку і викладачів вищих навчальних закладів навчалися в аспірантурі чи докторантурі в РФ, проходили там стажування, мали спільні проекти, практики тощо.

3 опитування стало зрозуміло, що на початку 2014 р. цей науковий світ кардинально змінився.

"Мої колеги та я не беремо участі в жодних наукових конференціях у Росії” (жінка вікової групи 61-70 років, Київ).

Значна кількість членів української географічної спільноти з тих чи інших причин більше не в змозі підтримувати зв'язок 3 російськими географами. Свідченнями такого розриву слугують відповіді, що стосуються зменшення кількості публікацій у виданнях російською мовою, відвідування конференцій у Росії, здійснення спільних проектів до і після 2014 р. Наприклад, якщо за період 2010-2013 рр. позитивну відповідь про наявність спільних публікацій з російськими колегами надали 19 респондентів (103 спільні публікації); то за період 2014-2018pp. позитивно відповіли 9 респондентів (17 спільних публікацій). Подібний спад відбувся щодо кількості публікацій російською мовою: 20102013 рр. - 47 позитивних відповідей (236 публікацій); 2014-2018 рр. - 32 (83 публікації). Також відбулося зменшенння кількості спільних проектів 3 росіянами: 29 було у період 20102013 рр. та лише 6 у наступний (2014-2018).

«Я втратила усі контакти в Росіі та Криму. Більше практично не використовую російську наукову літературу для досліджень чи викладання» - (жінка вікової групи 41-50 років, Київ).

Щодо питань, у яких виданнях географи хочуть опублікувати своє дослідження, домінує бажання розширити можливість публікації своїх наукових розробок у європейських виданнях, особливо За- 
хідної Європи. 44 респонденти (56 \%) відповіли, що хотіли б мати публікації у західноєвропейських журналах; 17 (22 \%) - в українських журналах, 12 (15\%) - у журналах Східної Свропи, 12 (15\%) - у журналах Північної Америки. Лише один респондент назвав російський журнал.

Підтвердженням намірів щодо пошуків альтернатив і звернення професійного мислення та поглядів на Захід, до наукових шкіл Східної та Західної Свропи, США та Канади стали зміни кількості англомовних публікацій протягом відповідних проміжків часу до та після вторгнення. 35 респондентів (159 публікацій) відповіли, що публікувалися англійською мовою у 2010-2013 роках, а за період 2014-2018 позитивну відповідь дали 44 респонденти (250 публікацій).

У наступному блоці питань респондентам запропонували повідомити з географами яких країн у них з'явилися нові контакти, яких не було до вторгнення, а також назвати дві країни, в яких вони б хотіли взяти участь у міжнародних конференціях. Названо 35 країн, відповіді демонструють бажання співпрацювати з більшою кількістю географів у європейських країнах, а також у країнах Північної Америки, в Австралії, Японії та Китаї.

Така ситуація значною мірою сприяє тому, що українська географія поступово відшукує новий, свій власний, науковий шлях, виходячи 3 стану наукової маргіналізації і здобуваючи ширше визнання.

\section{Вилив на особисте життя, сім'ю та друзів}

Окремий набір питань анкети стосувався впливу військового конфлікту на Сході України на рідне село чи місто. $3 / 4$ респондентів відповіли, що вплив був «значний» чи «певною мірою». Такі висновки корелюються з відповідями щодо того, як вторгнення вплинуло на сім'ю: 2/3 відмітили, що вплив на сім'ю «значний» чи «певною мірою». Респонденти описували вплив по-різному:

«Майже в кожній сім'їє чоловіки, які воювали чи зараз є військовослужбовиями» (жінка вікової групи 31-40 років, Кропивницький).

«У моєму місті багато біжениів, студентів $з$ тимчасово окупованих територій» (чоловік вікової групи 41-50 років, Дніпро).

«Місто напівзруйноване російсько-терористичними бандами, майже вся інтелектуальна еліта виїхала, мені також довелося змінити місие проживання» (жінка вікової групи понад 70 років, переселенка з Луганська).

«У зв'язку з російською агресією я, мої друзі та багато знайомих змінили иеркву. Ми більше не відвідуємо богослужіння в ичерквах Московського nатріархату» (жінка вікової групи 41-50 років, Київ).

Понад $85 \%$ респондентів заявили, що вторгнення «значно» чи «певною мірою» вплинуло на родичів та близьких друзів. У $58 \%$ респондентів розірвалися стосунки зі знайомими через вторгнення. Супровідні коментарі:

"Якщо говорити про мене особисто, вторгнення зачепило мої родинні стосунки більше, ніж наукову діяльність» (жінка вікової групи 51-60 років, Дніпро).

«Мої дві сестри живуть у Росї̈» (чоловік вікової групи понад 70 років, Одеса).

«Мій брат живе в Росії. Я не їздив до нього з 2014 року» (чоловік вікової групи 51-60 років, Рівне).

«Сімейні та дружні стосунки розірвані» (чоловіки вікових груп 61-70 та 31-40 років, Київ).

«Кардинально змінилося місие проживання, умови зайнятості, коло знайомих $і$ друзів, матеріальне забезпечення, світогляд, стан здоров'я тощьо» (жінка вікової групи 51-60 років, переселенка $з$ Луганська).

Щоб зрозуміти рівень громадянської активності респондентів окремі питання стосувалися їх залучення до роботи місцевих релігійних та громадянських спільнот, які надають допомогу біженцям зі Сходу України та АР Крим. 19 респондентів (24 \%) підтвердили, що вони працюють у таких групах, ще 42 (53\%) зазначили, що ï громади гостинно зустріли постраждалих 3 окупованих територій. Значна кількість респондентів не відповіли на ці запитання.

\section{Висновки і дискусія}

Проведене опитування членів Українського географічного товариства різного віку та статі, різної фахової підготовки, з різних поселень держави дають змогу зробити кілька важливих висновків.

По-перше, військове вторгнення РФ по-різному торкнулося викладачів закладів вищої освіти та науковців академічних установ. Для перших вторгнення значною мірою змінило сутність знань, що доноситься до студентів, організацію роботи (зміна змісту навчальних програм, місць проведення практик, передислокація установ, облаштування нових місць викладання і, відповід- 
но, життя та інше). Більшість нинішніх студентів ніколи не бували в Донбасі, чи в Криму. Для науковців виникли проблеми, більшою мірою пов' язані з призупиненням експедиційних досліджень та можливостями отримання нових даних про екологічний стан природного середовища та відсутністю актуальної статистики для Донецької і Луганської областей та АРК, що обмежує можливість здійснення комплексних досліджень. Інший вплив є дещо пом'якшеним через відсутність значної комунікації зі студентством та учнями. На ці результати впливає «наскільки далеко» розміщується фахівець від зони фактичного конфлікту, а також рівень особистого сприйняття ситуації [30].

По-друге, більшість респондентів відчули свою особисту відповідальність сприяти вирішенню складних питань, які відбуваються в державі. Це проявилось у зміні навчальних чи наукових програм, зміні сутності подання матеріалів, посиленні методів їх візуалізації. Стало зрозумілим, що вдосконалення просторових географічних знань призведе до кращого розуміння всіх, у тому числі негативних наслідків вторгнення. Зросла актуальність досліджень загроз суспільного розвитку, стану довкілля на окупованих і прилеглих до них територіях, міграції населення, особливостей впливу інформації різного типу та безпеки населення.

По-третє, відбулась певна переорієнтація у професійному житті географів: «орієнтуватись не тільки на Схід, а повернутись думками до Заходу». Це стосується здобування освіти, стажування, участі у конференціях, публікацій результатів досліджень у міжнародних журналах, вдосконалення мовного середовища. Звичайно, значним чинником цього $€$ також сучасні вимоги до науковців з боку МОН України. Однак, необхідно відмітити, що саме вторгнення послужило певним «тригером» як для початку реформ у сфері освіти і науки, так і для підняття потенціалу і рівня міжнародного визнання української географії.

Значною мірою російське військове вторгнення вплинуло на особисте життя географів, на їх родини і громади. Це стимулювало виникнення волонтерських рухів, сприяло консолідації зусиль громадян з метою надання допомоги українським військовим та вимушеним мігрантам. Однак, слід зауважити, що суспільство ще недостатньо зреагувало на виклики та загрози пов'язані з анексією Криму, російським військовим вторгненням на Сході України. Важливу участь тут має проявити і географія як світоглядна наука.

\section{Подяка}

Автори щиро вдячні всім членам Українського географічного товариства, які відповіли на питання, додали коментарі та зауваження і забезпечили можливість здійснити це дослідження.

\section{References [Лimepamypa]}

1. Shemshuchenko Yu.S. (2005). Final Act of the Conference on Security and Cooperation in Europe in 1975.

Encyclopedia of Ukrainian History. Vol. 3. Kyiv, 209 p. [In Ukrainian].

[Шемшученко Ю.С. Заключний акт наради з безпеки і співробітництва в Європі 1975 // Енциклопедія історії України: у 10 т. / редкол.: В. А. Смолій (голова) та ін. Київ. 2005. Т. 3. С. 209.]

2. Balabanov G. (2015). Modern Ukraine through cross-border population flows. Economic and social geography. Iss.1 (71). Kyiv, 10-17. [In Ukrainian].

[Балабанов Г. В. Сучасна Україна крізь призму транскордонних потоків населення // Економічна та соціальна географія: Наук. зб. Київ, 2015. Вип. 1 (71). С. 10-17.]

3. Pidhrushnyi H.P. (2017). Urbogenesis in Ukraine: determining factors, peculiarities of manifestation and main stages. Urban Ukraine: in the epicenter of spatial changes. Kyiv, 48-64. [In Ukrainian].

[Підгрушний Г.П. Урбогенез в Україні: визначальні чинники, особливості прояву та основні етапи // Урбаністична Україна: в епіцентрі просторових змін: монографія. Київ, 2017. С. 48-64.].

4. Ministry of Social Policy of Ukraine. Internally Displaced Persons. URL: https://www.msp.gov.ua/news/16541.html [In Ukrainian].

[Міністерство соціальної політики України. Внутрішньо переміщені особи. 2019. URL: https://www.msp.gov.ua/ news/16541.html]

5. Libanova E. M. (2015). Restoration of the Donbas: assessment of socio-economic losses and priority directions of public policy. Visnyk of the National Academy of Sciences of Ukraine, 11, 13-25. [In Ukrainian]

[Лібанова Е. М. Відновлення Донбасу: оцінка соціально-економічних втрат і пріоритетні напрями державної політики // Вісник Національної академії наук України. 2015. № 11. С. 13-25.]

6. Jaroscewicz M. (2015). The migration of Ukrainians in times of crisis. Central and Eastern European Online Library. 
OSW Commentary. URL: https://www.osw.waw.pl/en/publikacje/osw-commentary/2015-10-19/migration-ukrainianstimes-crisis

7. Davis C. M. (2016). The Ukraine conflict, economic-military power balances and economic sanctions. Post-Communist Economies, 28 (2), 167-198.

8. Environmental Assessment and Recovery Priorities for Eastern Ukraine. Report in the framework of the OSCE project Determining environmental damage in eastern Ukraine. (2017). Kyiv, 88 p. [In Ukrainian].

[Оцінка екологічної шкоди та пріоритети відновлення довкілля на сході України. Доповідь у рамках проекту ОБСЄ «Визначення шкоди навколишньому середовищу на сході України». К. 2017. 88 с.]

9. Toal G. (2017). Near Abroad: Putin, the West and the Context over Ukraine and the Caucasus. New York and London, $408 \mathrm{p}$.

10. Walker S. B. (2017). Long Hangover: Putin's New Russia and the Ghosts of the Past. New York, $288 \mathrm{p}$.

11. Kuzio T. (2017). Putin's War against Ukraine. Revolution, Nationalism and Crimea. Toronto, $490 \mathrm{p}$.

12. Kuzio T. (2018). Euromaidan revolution, Crimea and Russia-Ukraine war: Why it is time for a review of UkrainianRussian studies. Eurasian Geography and Economics, 59, 529-553.

13. Zubarevich N. (2015). Geopolitical priorities in Russia's regional policies. Russian Politics and Law, 53, 44-62.

14. Pleshakov C. (2017). The Crimean Nexus: Putin's War and the Clash of Civilizations. New Haven, $216 \mathrm{p}$.

15. Alikin A. (2017). Russian migration to 'Russify' Crimea. EurasiaNet 27 January. URL: https://eurasianet.org/russiamigration-helping-russify-crimea

16. Toal G. and O'Loughlin J (2016). From fragments, simmering spaces: The post-Soviet de facto state. Questioning Post Soviet. Washington, 103-126.

17. Uehling G. (2016). Everyday Afterlife after annexation: The Autonomous Republic of Crimea. Ukraine and Russia: People, Politics, Propaganda and Perspectives. Bristol, 66-75.

18. Maliarenko T. (2015). Playing a give-away game: The undeclared Russian-Ukrainian war in Donbas. Journal Article, 32.

19. Pew Research Center (2014). Despite Concerns about Governance, Ukrainians Want to Remain one Country. Washington. May 8. URL: http://www.pewglobal.org/2014/05/08/despite-concerns-about-governance-ukrainians-want-to-remainone-country/

20. Wilson A. (2014). Ukraine Crisis: What It Means for the West. New Haven, 248.

21. O'Loughlin J. and Toal G. (2019). The Crimea conundrum: Legitimacy and public opinion after annexation. Eurasian Geography and Economics, 60, 6-27. DOI: 10.1080/15387216.2019.1593973

22. Allison R. (2014). Russian 'deniable intervention' in Ukraine. How and why Russia broke the rules. International Affairs, 90 (6), 1255-1297.

23. Semigina T. and Gusak N. (2015). Armed conflict in Ukraine and social work response to it. Social, Health, and Communication Studies Journal, 2 (1), 1-24.

24. Roberts B. et al. (2019). Mental health care utilization among internally displaced persons in Ukraine; Results from a nation-wide survey. Epidemiology and Psychiatric Seines, 28 (1), 100-111.

25. Malyarenko T. and Wolff S. (2018). The logic of competitive influence-seeking: Russia, Ukraine, and the conflict in Donbas. Post-Soviet Affairs, 34 (4), 191-212.

26. Horbulin V. P., Vlasyuk O. S., Libanova E. M., Lyashenko O. M. (eds.) (2015). Donbass and Crimea: Return at What Price? Kyiv, 474 p. [In Ukrainian].

[Донбас і Крим: ціна повернення: монографія (за заг. ред. В.П. Горбуліна, О.С. Власюка, Е.М. Лібанової, О.М. Ляшенко). Київ. 474 с.]

27. Horbulin V. P. (2017). The World Hybrid War: Ukrainian Forefront: monography. Kyiv, 496 p. [In Ukrainian]. [Горбулін В. Світова гібридна війна: український фронт: монографія / за заг. ред. В.П. Горбуліна. Київ. 496 с.]

28. Horbulin V. P. (2017). Chronicles of predictions: 2006-2017. Kharkiv, 255 p. [In Ukrainian]. [Горбулін В. П. Хроніки передбачень: 2006 -2017. 2017. Харків. 255 с.]

29. Libanova E. M., Horbulin V. P., Pyrozhkov S. (2015). Policy of integration of Ukrainian society in the context of challenges and threats of events in the Donbass. Kyiv, 363 p. [In Ukrainian].

[Лібанова Е. М., Горбулін В. П., Пирожков С. І. Політика інтеграції українського суспільства в контексті викликів та загроз подій на Донбасі (національна доповідь) / за ред. Е. М. Лібанової. Київ. 363 с.]

30. Brunn S. D., Dronova O., Rudenko L., Leiberiuk O. (2019). Disruption, despair and renewal: impacts and voices of the Ukrainian geographical community about the 2014 Russian invasion. Geografiska Annaler: Series B. Human Geography. DOI: $10.1080 / 04353684.2019 .1708013$

Стаття надійшла до редакції 04.03.2020 